\title{
Influenza A(H1N1)pdm09 in England, 2009 to 2011: a greater burden of severe illness in the year after the pandemic than in the pandemic year
}

O T Mytton ${ }^{1}$, P D Rutter ${ }^{2}$, L J Donaldson (liam.donaldson@npsa.nhs.uk)²

1. University of Oxford, Oxford, United Kingdom

2. Imperial College London, London, United Kingdom

Influenza pandemics are often perceived as singleyear events, but the burden of previous influenza pandemics has in reality been spread over a number of years. The aim of this paper is to compare the burden of influenza in the pandemic year 2009/10 with that in the year immediately after (2010/11) in England. We compared four measures of disease. There was a greater burden of severe illness in 2010/11 compared with 2009/10: more deaths (474 vs 361), more critical care admissions $(2,200$ vs 1,700$)$, and more hospital admissions $(8,797$ vs 7,879$)$. In contrast, there were fewer general practice consultations in 2010/11 compared with $2009 / 10$ (370,000 vs 580,000 ). There was also much less public interest in influenza, as assessed by number of Google searches. This is a worrying finding, as by the time of the second influenza season, much had been learnt about the potential impact of the influenza $A\left(\mathrm{H}_{1} \mathrm{~N}_{1}\right)$ pdmog virus and an effective vaccine developed. We suggest that a widespread assumption of 'mildness' led to insufficient ongoing action to prevent influenza and hence to avoidable influenza-related deaths. This offers a lesson to all countries, both for future influenza seasons and for pandemic preparedness planning.

\section{Introduction}

The public perception of influenza pandemics tends to be as single-year events. Contingency plans also assume that a new virus emerges and sweeps through the population, causing infection and death over a single year [1-4]. History, however, tells a different story. Previous pandemics have involved waves over multiple years, each causing pronounced mortality [1]. The $1968 / 69$ pandemic was described as the 'smouldering pandemic'. In England and other European countries, its burden was greater in the 1969/70 influenza season than in the $1968 / 69$ season [5].

When illness associated with the influenza $A\left(\mathrm{H}_{1} \mathrm{~N}_{1}\right)$ pdmog virus (initially dubbed 'swine flu') was detected in April 2009, the public health response in England was intensive. In an initial containment phase, all contacts of cases were identified and treated with antiviral medication, to minimise spread of the virus. Schools were closed or partially closed. When increasing levels of influenza put serious pressure on the capacity of general practices to cope, a novel telephone and Internet-based system was introduced to mitigate this. This system, the National Pandemic Flu Service, ensured the public had ready access to antivirals. A widespread social marketing campaign, 'Catch it. Bin it. Kill it', emphasised the importance of hygiene measures (cough etiquette, hand washing) [6]. The pandemic also received extensive media coverage.

Fortunately the virus, and the pandemic, was milder than many had initially feared. Some criticised the government measures in the United Kingdom as a costly overreaction $[7,8]$, though a formal inquiry into the management of the pandemic called the overall response 'highly satisfactory' [9].

In contrast, in the year after the pandemic, early comments from both from the Health Protection Agency and Department of Health were generally reassuring about the likely impact of influenza in the coming weeks $[10,11]$. The usual national advertising campaign to promote the seasonal influenza vaccine was not run [12]. When the number of severe cases rose and there were influenza-related deaths, the government was consequently criticised for complacency [13].

This study uses a number of objective measures to assess how the burden of influenza $A\left(\mathrm{H}_{1} \mathrm{~N}_{1}\right)$ pdmog in the year after the pandemic compared with that in the pandemic year itself.

\section{Methods}

Using published sources, we compared the burden of influenza in the pandemic year (2009/10) with that in the following year (2010/11) using four measures that were replicable across the two years. We also assessed public interest in influenza and antiviral usage over the same time period. 
General practice consultations

The Royal College of General Practitioners (RCGP) has undertaken surveillance of influenza-like illness (ILI) (clinically defined) in general practice for over 40 years. The system uses around 100 sentinel general practices across England, covering a population of approximately 800,000 . The system extracts summary information (based on read codes [14]) from general practice electronic records. This is used to estimate the rate of ILI consultations in the population of England as a whole. These estimates, by age and week of consultation, were supplied by the RCGP Research \& Surveillance Centre. We used these, together with mid-2009 population estimates from the Office for National Statistics [15], to estimate the total number of ILI consultations in England in each year.

\section{Hospital admissions}

Information on hospital admissions was extracted from Hospital Episode Statistics (HES) [16]. This database contains details of all admissions to National Health Service (NHS) hospitals in England. Admission details are coded locally and uploaded to a central database. Two particular codes are used for influenza-related admissions: International Classification of Diseases (ICD) codes J10: influenza due to other identified influenza virus or J11: influenza, virus not identified). Instances of these codes were extracted by age and by week of hospital admission.

\section{Intensive care admissions}

During the pandemic and the following year, all acute NHS hospitals reported both influenza-related critical care bed occupancy data (in 'bed-days') and the number of critical-care beds occupied at 8 a.m. on Wednesday mornings by age group to the Department of Health. These data recorded both suspected and confirmed cases of influenza. Suspected cases were those who were being treated for influenza on the basis of clinical suspicion but awaiting laboratory microbiological confirmation. Confirmed cases were those in whom the diagnosis had been confirmed by a specific microbiological test.

A national surveillance system in the pandemic year calculated the mean influenza-related length of stay in critical care as seven days [17]. We therefore estimated the number of admissions to critical care by dividing the total number of reported critical care bed days by seven. Critical care bed occupancy data were only recorded from 12 July 2009 to 21 February 2010 and from 20 December 2010 to 20 January 2011.

\section{Deaths}

During the pandemic year, a special reporting system provided details of influenza-related deaths to England's Chief Medical Officer [18-20]. Deaths were considered influenza-related if the virus had been laboratory-confirmed, if influenza was recorded on the death certificate, or both. During the following year, the Health Protection Agency ran a similar system. Its definition of an influenza-related death was slightly narrower, requiring both laboratory confirmation and the recording of influenza on the death certificate [21].

\section{Public interest in influenza}

A proxy chosen for public awareness of - and interest in - influenza was Google data on the rate at which particular search terms were used in its Internet search engine. We downloaded data describing the volume of searches for the term 'flu' by week in the United Kingdom. The absolute number of searches was not made available, thus the data describe the relative volume between weeks.

\section{Defining the influenza season}

In England, the influenza season runs from the start of October to the start of April, with peak activity typically in December and January [22]. As the pandemic virus circulated outside the usual influenza season, however, we defined the pandemic year as starting when general practice consultations due to ILI first rose above 30 per 100,000 people per week, the threshold for normal seasonal influenza activity. In the year following the pandemic, we defined the start as being the usual start of an influenza season, i.e. the start of October. For both years, we defined the season end as the end of February. Thus the two seasons analysed were 29 June 2009 to 28 February 2010 (pandemic year) and 4 October 2010 to 27 February 2011 (second year).

\section{Antiviral prescribing data}

Data describing the number of antiviral medication (oseltamivir and zanamivir) courses dispensed by pharmacists in the community in England were provided by the NHS Business Services Authority. Equivalent data were published by the National Pandemic Flu Service, describing the number of courses dispensed through this service, which was established specifically for the pandemic. Data on the number of courses of antiviral medication (oseltamivir or zanamivir) dispensed were published by the National Pandemic Flu Service.

Oseltamivir and zanamivir are prescription-only medications. An electronic record of all prescriptions processed by community pharmacists is sent to the central NHS Prescription Services, in order for the pharmacist to receive reimbursement. These data are pooled to produce the total number of prescriptions of each discrete pharmaceutical item listed in the British National Formulary [23]. Although the data do not include private prescriptions, by including all prescriptions issued by the NHS, they will include the vast majority of prescriptions issued in the community in England.

\section{Results}

Three distinct waves of influenza activity occurred during the two-year period (Figures 1 and 2): two during the pandemic year $(2009 / 10)$ and a single wave in the second year (2010/11). 
Influenza-related general practice consultations and hospital admissions, England, 5 January 2009-13 March 2011

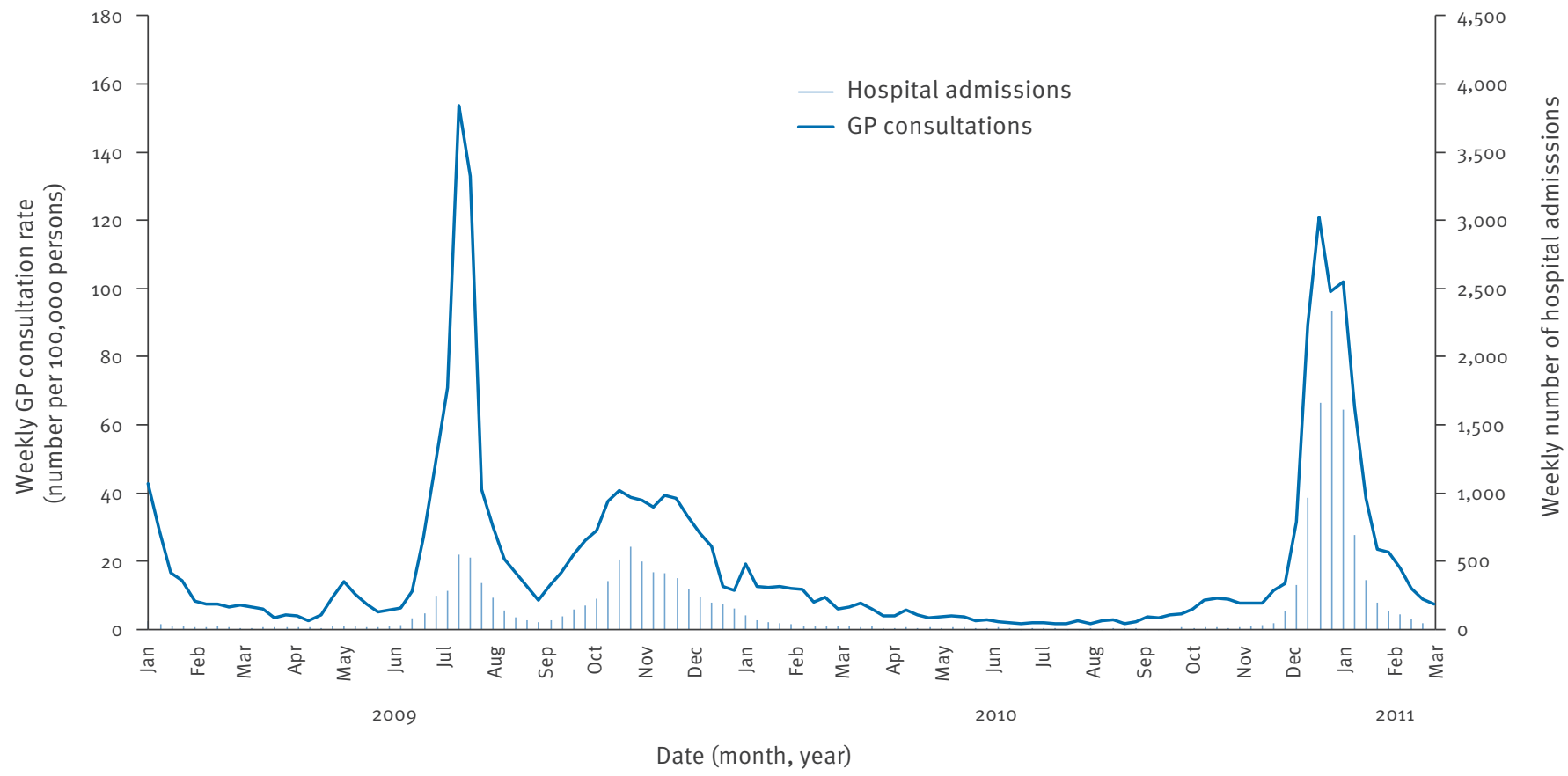

GP: general practice.

\section{FIGURE 2}

Influenza-related critical care admissions and deaths, England, 15 June 2009-13 March 2011

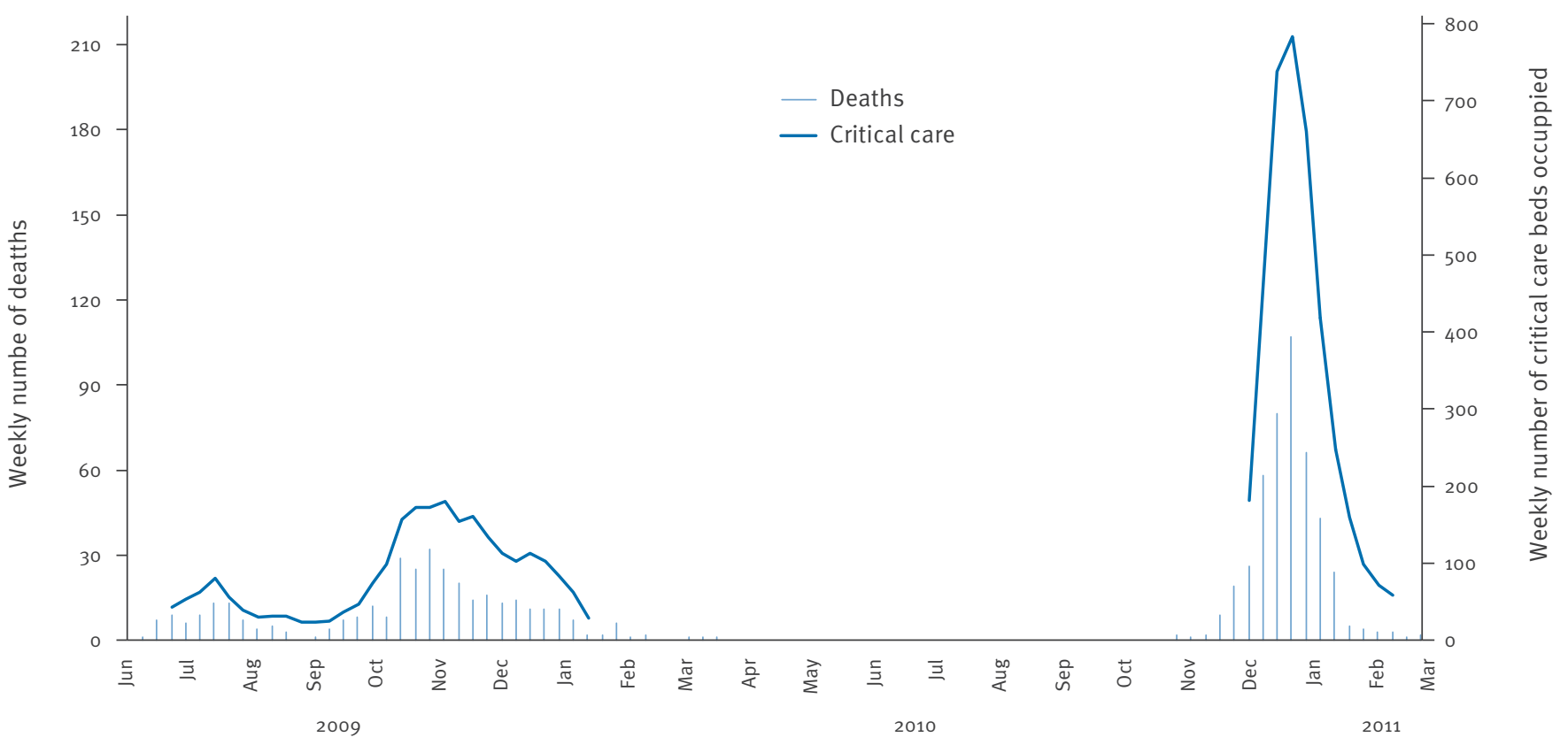

Date (month, year) 
The first wave occurred in July and August 2009, peaking 12 weeks after the first case of influenza $A\left(\mathrm{H}_{1} \mathrm{~N}_{1}\right)$ pdmog was reported in England. This wave was characterised by a short sharp rise and fall in influenza activity, as assessed both by general practice consultations and hospital admissions.

The second wave occurred in autumn 2009. There was a gradual and prolonged rise in influenza activity that lasted for several weeks. Assessed by general practice consultations, the incidence of influenza in the community was lower than in the first wave. However, rates of influenza activity in hospital were much greater than those in the first wave.

\section{TABLE 1}

Influenza-related general practice consultations, hospital admissions, critical care admissions and deaths, England, pandemic year 2009/10 and second year 2010/11

\begin{tabular}{|l|c|c|}
\hline \multirow{2}{*}{$\begin{array}{l}\text { Type of influenza-related } \\
\text { event }\end{array}$} & \multicolumn{2}{|c|}{\begin{tabular}{c} 
Number of events \\
\cline { 2 - 3 }
\end{tabular}} \\
\cline { 2 - 3 } & $\begin{array}{c}\text { Pandemic year } \\
2009 / 10^{\mathrm{a}}\end{array}$ & $\begin{array}{c}\text { Second year } \\
2010 / 11^{\mathrm{a}}\end{array}$ \\
\hline $\begin{array}{l}\text { Number of general practice } \\
\text { consultations }\end{array}$ & 580,000 & 370,000 \\
\hline $\begin{array}{l}\text { Number of hospital } \\
\text { admissions }\end{array}$ & 7,879 & 8,797 \\
\hline $\begin{array}{l}\text { Number of critical care } \\
\text { admissions }\end{array}$ & 1,700 & 2,200 \\
\hline Number of deaths & 361 & $474^{\mathrm{b}}(436)$ \\
\hline
\end{tabular}

a Pandemic year: 29 June 2009 to 28 February 2010. Second year: 4 October 2010 to 27 February 2011.

b Deaths reported by the Health Protection Agency from 4 October 2010 to 4 May 2011. The number in parentheses is the estimated number of deaths due to influenza $A\left(\mathrm{H}_{1} \mathrm{~N}_{1}\right)$, based on $91.9 \%$ of all influenza-related deaths in the United Kingdom being attributable to influenza $A\left(\mathrm{H}_{1} \mathrm{~N}_{1}\right)$ [21].
The third wave occurred in December 2010 and January 2011 and was characterised by a short sharp rise and fall in influenza activity. This wave was associated with greater peaks in hospital and critical care admissions than either of the previous two waves.

Overall, the burden of severe illness caused by influenza (deaths, critical care and hospital admissions) was greater in the second year than the pandemic year (Table 1). There were approximately $10 \%$ more hospital admissions, $30 \%$ more deaths and 30\% more critical care admissions in the second year than in both waves of the pandemic year combined. The reverse was true for general practice consultations: there were approximately $35 \%$ fewer of these in the second year than in the pandemic year.

Influenza activity in the second year was concentrated far more intensively than in the pandemic year. Most of the activity was concentrated in an eight-week period. The busiest four weeks in the second year involved three times as many hospital admissions as the busiest four weeks in the pandemic year (20 December 2010 to 16 January 2011: 1,643 admissions per week; 2 November 2009 to 30 November 2009: 510 admissions per week). Similarly, there were over three times as many critical care admissions per week over the same periods (mean critical care bed occupancy: 661 vs 170 ). The peak weekly hospital admission rate in the second year was more than three times that of the pandemic year (week ending 2 January 2011: 2,334 admissions; week ending 3 October 2009: 604 admissions). The peak critical care bed occupancy in the second year was four times that of the pandemic year $(851$ beds on 4 January 2011, compared with a peak of 196 in November 2009).

\section{TABLE 2}

The age distribution of influenza-related general practice consultations, hospital admissions, critical care admissions and deaths, England, pandemic 2009/10 and second year 2010/11

\begin{tabular}{|c|c|c|c|c|c|}
\hline \multirow{2}{*}{ Type of influenza-related event } & \multicolumn{4}{|c|}{ Number of events (\%) by age group } & \multirow{2}{*}{$\begin{array}{c}\text { Chi-square test } \\
\text { p value }\end{array}$} \\
\hline & $0-4$ years & $5-14$ years & $15-64$ years & $\geq 65$ years & \\
\hline \multicolumn{6}{|c|}{ Number of general practice consultations } \\
\hline Pandemic year ${ }^{\mathrm{a}}$ & $61,000(11)$ & $94,000(16)$ & $390,000(67)$ & $34,000(6)$ & \multirow{2}{*}{$<0.001$} \\
\hline Second year ${ }^{\mathrm{a}}$ & $25,000(7)$ & $42,000(11)$ & $280,000(74)$ & $27,000(7)$ & \\
\hline \multicolumn{6}{|l|}{ Number of hospital admissions } \\
\hline Pandemic year & $1,790(27)$ & $1,182(15)$ & $4,429(56)$ & $478(6)$ & \multirow{2}{*}{$<0.001$} \\
\hline Second year & $1,551(18)$ & $461(5)$ & $5,797(66)$ & 988 (11) & \\
\hline \multicolumn{6}{|c|}{ Mean number of critical care beds occupied ${ }^{b}$} \\
\hline Pandemic year & $7.8(10)$ & $4.9(5)$ & $59(73)$ & $8.7(11)$ & \multirow{2}{*}{0.067} \\
\hline Second year & $15.8(4)$ & $7.9(2)$ & $280(80)$ & $47(13)$ & \\
\hline \multicolumn{6}{|l|}{ Number of deaths } \\
\hline Pandemic year (England only) & $22(6)$ & $35(10)$ & $240(66)$ & $64(18)$ & \multirow{2}{*}{0.004} \\
\hline Second year (United Kingdom) $^{c}$ & $25(4)$ & $25(4)$ & $415(71)$ & $122(21)$ & \\
\hline Population in England (millions) & $3.2(6)$ & $5.9(11)$ & $34.3(66)$ & $8.4(16)$ & \\
\hline
\end{tabular}

a Pandemic year: 29 June 2009 to 28 February 2010. Second year: 4 October 2010 to 27 February 2011.

b Counted at 8 a.m. on Wednesdays.

Only includes those for whom age at death was known. 
For every 10,000 general practice consultations in 2009/10 there were 136 hospital admissions, 29 critical care admissions and six deaths. The respective numbers for 2010/11 were approximately twice as great, being 238 hospital admissions, 59 critical care admissions and 13 deaths. In contrast, measures of severe illness had similar ratios between the two seasons. For every 1,000 hospital admissions in 2009/10 there were 215 critical care admissions and 45 deaths. In 2010/11, the respective numbers were 250 critical care admissions and 53 deaths.

In the second year, the younger age groups (0-4 years, 5-15 years) were less prominently affected than in the pandemic year. The burden shifted towards workingage people (16-64 years) and the elderly (Table 2 , chisquare $p<0.001$ for general practice consultations and hospital admissions). This shift was seen consistently across all measures of influenza activity.

Public interest in influenza, indicated by volume of Internet searches, showed four peaks of activity (Figure 3). The first occurred in April 2009, when the new strain of the virus was first widely publicised, leading to worldwide concern about an imminent pandemic. The second peak in interest occurred in July 2009, coinciding with the first wave of influenza activity in England. Two further, smaller peaks coincided with the second and third waves of influenza activity in England. Public interest relative to the burden of influenza (as measured by number of hospital admissions per week) was relatively high during the first wave of activity, lower during the second wave of activity and very low in the third wave. Public interest in influenza was four times as great in July 2009 as in January 2011, whereas the rate of hospital admission was four times as great in January 2011 as in July 2009.

During the pandemic year, the National Pandemic Flu Service operated from 23 July 2009 to 11 February 2010. It dispensed 1,161,157 courses of antiviral medication during this time. Community pharmacists dispensed fewer courses: 10,610 in the pandemic year (June to February) and 38,692 in the second year (October to February). Overall, 30 times more courses of antiviral medication were dispensed in the pandemic year than in the following year $(1,171,767$ vs 38,692 courses).

\section{Discussion}

In England, influenza $\mathrm{A}\left(\mathrm{H}_{1} \mathrm{~N}_{1}\right)$ pdmog caused more hospital admissions, more critical care admissions and more deaths in its second year of circulation than in the pandemic year itself. There were fewer general practice consultations and there was less public interest in influenza in the second year than in the pandemic year. This is a worrying finding given that an effective vaccine was available for the duration of the influenza season following the pandemic year.

\section{Ascertainment bias is unlikely}

We looked at whether systematic differences in the methods of ascertainment or changes to the definitions of any of the measures analysed between the two years could explain this difference. The case definition of a death was actually narrower in the second year than in the pandemic year. For hospital and critical care admissions, the case definitions and ascertainment methods were the same in both years. However, the system for reporting critical care admissions in the second year was not established until mid-December,

\section{FIGURE 3}

Hospital admissions for influenza and Google searches for 'flu', England, 19 January 2009-27 February 2011

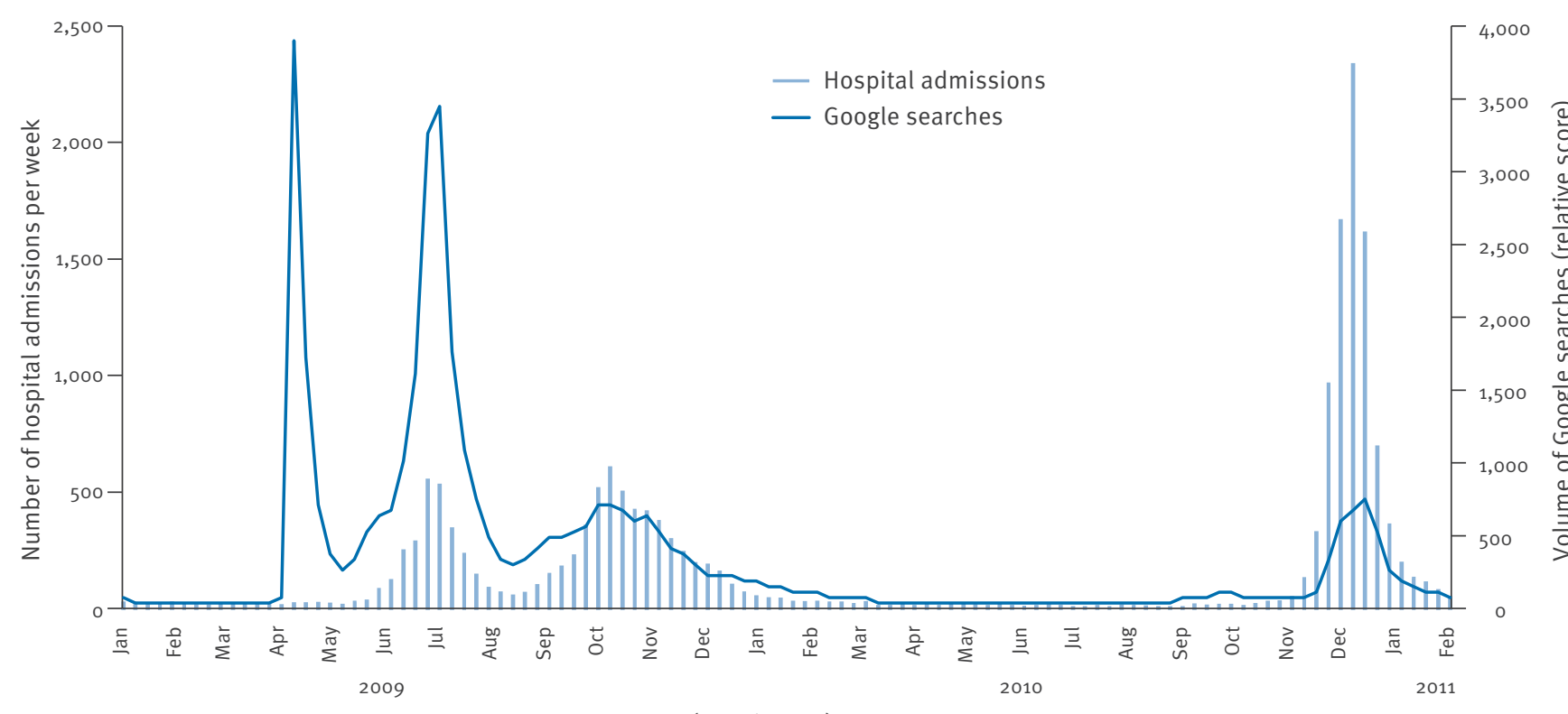

Date (month, year) 
after many admissions are likely to have occurred. For all these reasons, both deaths and critical care admissions are likely to have been underestimated in the second year relative to the pandemic year. It therefore seems unlikely that systematic differences in ascertainment can explain the principal finding of our study.

Could ascertainment of deaths, critical care and hospital admissions have been increased by enhanced clinical awareness of influenza, leading to greater testing for, and diagnosis of, the disease? This seems highly implausible. Public awareness and clinical awareness of influenza was markedly lower in the second year. Why would England be alone among western countries in experiencing a phenomenon of increased clinical diagnosis and reporting of influenza in the second year relative to the pandemic year? No such effect was found in the United States, Canada, Australia or New Zealand. If anything, clinical ascertainment of cases in England is likely to have been greater in the pandemic year, when there was huge media interest in this novel event and clinicians' awareness of the circulation of the virus was high. Moreover, there was a great deal of communication between the government and front-line clinicians. This would all suggest that the true difference between the two years was in fact greater than that reported here.

The methods of influenza surveillance in general practice in England are long established and unchanged in recent years. The existence of the National Pandemic Flu Service from July 2009 until February 2010 was intended to reduce the burden on general practice. No equivalent system existed in the second year. General practice consultation rates are therefore likely to be relatively suppressed in the pandemic year compared with the second. Again, this suggests that the difference between the two years reported here is a highly conservative estimate.

Finally, all three measures of severe illness showed similar changes. We have also heard anecdotal accounts from intensive care physicians that the 2010/11 influenza season brought with it serious cases of influenza in previously healthy young individuals on a scale that appeared worse than in the pandemic itself. Taken together, this leaves little room for doubt that there was a genuine increase in hospital and critical care admissions and in deaths between the two years.

\section{Most countries did not suffer}

a worse second year

International comparisons are somewhat difficult because of uncertainty about the quality of surveillance across the two years. Those comparisons that can be made suggest that England's experience is unusual. In the second year, the United States experienced lower peak ILI consultations ( $4.6 \%$ vs $7.7 \%$ of weekly outpatient visits), fewer paediatric deaths (105 vs 282) and a lower hospitalisation rate (19.1 per 100,000 population vs 29.0 per 100,000 population) than in the pandemic year [24]. New Zealand reported a lower peak ILI rate ( 150 per 100,000 in 2010 vs 275 per 100,000 in 2009), fewer hospital admissions (998 vs 1,517) and fewer deaths ( 16 vs 35 ) [25]. Similar patterns were seen in Canada and Australia [26-28].

The European picture is less clear [29], but many European countries have reported fewer cases of severe illness and fewer deaths in the second year [30,31]. Only the experience of Ireland, Greece and the other UK nations looks similar to that of England. Ireland had small increases in the numbers hospitalised, treated in critical care and dying $[32,33]$. Greece experienced more intensive care admissions and fatal cases in the post-pandemic season than in the pandemic season ( 368 vs 294 and 180 vs 149 respectively), although the magnitude was not on the same scale as in England [34]. Broadly, the English pattern was replicated in the other UK nations, with higher peak levels of influenza activity in 2010/11 and similar or slightly more deaths (69 deaths in Scotland in 2009/10 vs 63 in 2010/11, Wales 28 vs 34, Northern Ireland 18 vs 31) $[9,21]$.

\section{Government response was the major}

difference between the two years

What could explain the greater burden of severe illness in the second year? The virus has been closely observed. Its genetic composition had not changed [21]. Influenza B virus was more evident in the second year than in the pandemic year. It was the causative agent detected in $24.1 \%$ of positive influenza specimens (compared with just $0.3 \%$ in the pandemic year) but accounted for just $6.6 \%$ of deaths [21]. There were anecdotal reports of serious illness caused by coinfection in the second year, but the total number of these reports is not great $[2,35,36]$. While the small shift in age distribution towards older age groups, who are more prone to the severe effects of influenza, will have contributed to the greater burden of severe illness [34], similar shifts have been seen elsewhere but not resulted in a greater burden of severe illness [28]. Peak transmission in the second year occurred later in the year, when the weather in England was colder and drier. This may have had a role in facilitating greater transmission of the virus in the second year [37-39].

However, the most notable difference between the two years was the government response. The public health response in the pandemic year was highly assertive. Strong public awareness and education campaigns were run. Extensive and rolling media coverage throughout the duration of the emergency is likely to have enhanced public understanding. Antiviral drugs were widely used for symptomatic individuals and (in the early phase) their contacts. Schools were closed, with antiviral treatment of cases and contacts. Unlike previous influenza pandemics, a vaccine was made available and used before the end of the pandemic year.

In contrast, in the influenza season that followed the pandemic year, the approach was laissez-faire. The 
traditional influenza public awareness campaign was cancelled. There was no attempt to warn about the likelihood that the pandemic virus would be circulating (thus affecting younger age groups). There was no drive to vaccinate children, although it is unclear to what extent this was influenced by emerging concerns about pandemic vaccine safety in children and adolescents $[40,41]$. The National Pandemic Flu Service was not activated and antivirals were not used extensively.

The 30 -fold difference in antiviral usage between the two years is profound. The widespread use of antiviral medication in the community combined with public awareness during the pandemic year is likely to have led to early treatment. This is likely to be important in preventing adverse outcomes, such as hospitalisation, critical care admission and death $[42,43]$. A reduction in virus transmission, particularly among children [4345], from widespread antiviral use may also have contributed to the reduced burden of severe illness in the pandemic year. Other public health measures may also have had an important impact on the emerging disease $[46,47]$.

Some countries took a very proactive approach to immunisation in the second year. New Zealand achieved record levels of immunisation [25]. In the United States, the Centers for Disease Control and Prevention emphasised the special importance of vaccination, extending its availability to all healthy adults [48].

In England, when the virus began to circulate in early December 2010, uptake of vaccine among the eligible groups aged six months to 65 years was only about $40 \%$ [49]. The final uptake figures, at around 50\%, were comparable to the pandemic year [50]. Given that this group was at increased risk of severe complications in comparison with a typical influenza season, it is disappointing that higher levels of immunisation were not achieved, particularly as influenza causes more deaths among those aged under 65 years than any other vaccine-preventable disease $[19,51,52]$.

Reduction in general practice consultation rates What might account for the reduction in general practice consultation rates between the two years? These rates are driven by the incidence of influenza and by the proportion of those affected who seek care. Given the greater burden of severe illness in the second year without any change in the virus itself, it seems unlikely that the incidence of influenza was lower in the second year than in the pandemic year. Consistent with the demonstrated lower level of public interest, it seems likely that the public were less likely to consult when symptomatic in the second year.

A lower rate of general practice consultations might itself have contributed to higher rates of severe illness. It is likely to have contributed to delayed and lower use of antivirals. It is also possible that the detection of superimposed bacterial illness or other severe illness may have been delayed.

\section{Predictable age distribution: younger than those with typical seasonal influenza}

Both years saw a high ratio of young to elderly influenza deaths in comparison with that seen in a typical influenza season. The second year saw a small shift away from the younger age groups towards adults of working age. This is consistent with past influenza behaviour. Analysing historical influenza mortality data from the United States, Simonsen et al. have shown that a marked shift in mortality away from the elderly to the young has occurred in the first year of previous pandemics [53]. This shift persists, slowly drifting back towards the elderly over a period of 10 to 20 years. Influenza $\mathrm{A}\left(\mathrm{H}_{1} \mathrm{~N}_{1}\right)$ pdmog is so far behaving similarly. This shows the importance not only of remaining vigilant after the first passing of the pandemic wave, but also of maintaining heightened vigilance for several years after.

\section{Conclusion}

England experienced a greater burden of severe illness due to influenza $A\left(\mathrm{H}_{1} \mathrm{~N}_{1}\right)$ pdmog in the second year of its circulation than in the pandemic year. The difference appears to be real rather than fallacious. By the time of the second influenza season, much had been learnt about the potential impact of the virus and an effective vaccine developed. Despite this, a large number of deaths, critical care and hospital admissions occurred, many of these in otherwise healthy people of working age. The differences in the government response over the two years were striking and likely to have contributed to the increased impact of the disease in the second year.

\section{References}

1. Miller MA, Viboud C, Balinska M, Simonsen L. The signature features of influenza pandemics - implications for policy. $\mathrm{N}$ Engl J Med. 2009;360(25):2595-8.

2. Department of Health. Pandemic flu - a national framework for responding to an influenza pandemic. London: Department of Health; 2007. Available from: http://www. dh.gov.uk/en/Publicationsandstatistics/Publications/ PublicationsPolicyAndGuidance/DH_080734

3. Unites States Department of Health and Human Services (HSS). HHS pandemic influenza plan.,Washington DC; HHS; 2005. Available from: http://www.flu.gov/planning-preparedness/ federal/hhspandemicinfluenzaplan.pdf

4. Public Health Agency of Canada. The Canadian pandemic influenza plan for the health sector. Ottawa: Public Health Agency of Canada; 2006. [Accessed 7 Jul 2011]. Available from: http://www.phac-aspc.gc.ca/cpip-pclcpi/

5. Viboud C, Grais RF, Lafont BA, Miller MA, Simonsen L; Multinational Influenza Seasonal Mortality Study Group. Multinational impact of the 1968 Hong Kong influenza pandemic: Evidence for a smoldering pandemic. J Infect Dis 2005;192(2):233-48.

6. Department of Health. Catch it. Bin it. Kill it. London: Department of Health; April 2009. Available from: http://www. dh.gov.uk/en/MediaCentre/Media/DH_o98663

7. Marsden S, Conway JSwine flu outbreak cost UK $f 1.2 b n$. The Independent, 1 July 2010. Available from: http://www. independent.co.uk/life-style/health-and-families/health-news/ swine-flu-outbreak-cost-uk-pound12bn-2015429.html

8. Laurance J. The swine flu backlash. Lancet. 2010;375(9712):367. 
9. Hine D. The 2009 influenza pandemic. An independent review of the UK response to the 2009 influenza pandemic. London: Cabinet Office; 2010. Available from: http://webarchive. nationalarchives.gov.uk/+/http://www.cabinetoffice.gov.uk/ media/416533/the2ooginfluenzapandemic-review.pdf

10. Laurance J. Britain's flu death rate is the highest in Europe. The Independent, 24 December 2010. Available from: http://www. independent.co.uk/life-style/health-and-families/health-news/ britains-flu-death-rate-is-the-highest-in-europe-2168432.html

11. Briggs H. GPs report flu cases rose again last week. BBC News, 29 December 2010. Available from: http://www.bbc.co.uk/ news/health-12089488

12. Campbell D, Boseley S. Swine flu: top doctor warns of crisis as few have $\mathrm{H}_{1} \mathrm{~N}_{1}$ jab. The Guardian, 21 December 2010. Available from: http://www.guardian.co.uk/world/2010/dec/21/ swine-flu-top-doctor-crisis

13. British Broadcasting Corporation (BBC). 'Government accused of 'misjudgement' over flu outbreak. BBC. [Accessed 13 Mar 2012]. Available from: http://news.bbc.co.uk/democracylive/ hi/house_of_commons/newsid_9354000/9354802.stm

14. National Health Service Connecting for Health (NHS CFH). Read codes. NHS CFH. [Accessed 13 Mar 2012]. Available at: http:// www.connectingforhealth.nhs.uk/systemsandservices/data/ uktc/readcodes

15. Office for National Statistics (ONS). Population estimates for England, mid 2009. ONS; 2010. [Accessed 7 Jul 2011]. Available from: http://www.ons.gov.uk/ons/publications/re-referencetables.html?edition $=\mathrm{tcm} \% 3 \mathrm{~A} 77-213645$

16. The Health and Social Care Information Centre. Hospital episode statistics. The Health and Social Care Information Centre. [Accessed 28 Mar 2012]. Available from: http://www. hesonline.nhs.uk

17. Campbell CN, Mytton OT, McLean EM, Rutter PD, Pebody RG, Sachedina N, et al. Hospitalization in two waves of pandemic influenza $A\left(\mathrm{H}_{1} \mathrm{~N}_{1}\right)$ in England. Epidemiol Infect. 2011; 139(10):1560-9.

18. Donaldson LJ, Rutter PD, Ellis BM, Greaves FE, Mytton OT, Pebody RG, et al. Mortality from pandemic A/H1N1 2009 influenza in England: public health surveillance study. BMJ. 2009;339:b5213.

19. Sachedina N, Donaldson LJ. Paediatric mortality related to pandemic influenza $\mathrm{A} \mathrm{H} 1 \mathrm{~N}_{1}$ infection in England: an observational population-based study. Lancet. 2010;376(9755):1846-52.

20. Mytton OT, Rutter PD, Mak M, Stanton EA, Sachedina N, Donaldson LJ. Mortality due to pandemic ( $\left.\mathrm{H}_{1} \mathrm{~N}_{1}\right) 2009$ influenza in England: a comparison of the first and second waves. Epidemiol Infect. 2011 Nov 1:1-9. [Epub ahead of print].

21. Health Protection Agency (HPA). Surveillance of influenza and other respiratory viruses in the UK. 2010-2011 report. London: HPA; May 2011. Available from: http://www.hpa.org.uk/webc/ HPAwebFile/HPAweb_C/1296687414154

22. Health Protection Agency (HPA). October - flu season and HPA flu surveillance begins. London: HPA; 6 Oct 2010. Available from: http://www.hpa.org.uk/NewsCentre/NationalPressRelea ses/2010PressReleases/101006flu/

23. Joint Formulary Committee. British National Formulary (BNF) 62. London: Pharmaceutical Press; 2011.

24. Centers for Disease Control and Prevention (CDC). Situation update: summary of weekly FluView. Atlanta: CDC; 2011. [Accessed 7 Jul 2011]. Available from: http://www.cdc.gov/flu/ weekly/summary.htm

25. Lopez L, Bandaranayake D, Huang QS. Influenza surveillance in New Zealand 2010. Wellington: Institute of Environmental Science and Research Ltd; 2011. Available from: http:// www.surv.esr.cri.nz/PDF_surveillance/Virology/FluAnnRpt/ InfluenzaAnn2010.pdf

26. Public Health Agency of Canada. Flu Watch - January 30 to 5 Febrary, 2011 (week 05). Public Health Agency of Canada; February 2011. [Accessed 7 Jul 2011]. Available from: http:/ www.phac-aspc.gc.ca/fluwatch/10-11/w05_11/index-eng.php

27. Public Health Agency of Canada. Flu Watch - January 31 to 6 Feburary, 2010 (week 5). Public Health Agency of Canada; February 2010. [Accessed 7 Jul 2011]. Available from: http:// www.phac-aspc.gc.ca/fluwatch/09-10/w05_10/index-eng.php

28. Department of Health and Ageing. Australian influenza surveillance report. No. 44,2010 , reporting period: 30 October - 5 November 2010. Canberra: Department of Health and Ageing, 2010. Available from: http://www.health.gov.au/ internet/main/publishing.nsf/Content/44CA16D6D75F4F13CA25 77DBo07A33EC/\$File/ozflu-n044-2010.pdf

29. Review of the 2010-2011 winter influenza season, northern hemisphere. Wkly Epidemiol Record. 2011;86(22):222-7.
30. European Centre for Disease Prevention and Control (ECDC). Weekly influenza surveillance overview. 28 May 2010. Stockholm: ECDC; 2010. Available from: http://ecdc.europa.eu/ en/publications/Publications/100528_SUR_Weekly_Influenza_ Surveillance_Overview.pdf

31. European Centre for Disease Prevention and Control (ECDC). Weekly influenza surveillance overview. 27 May 2011. Stockholm: ECDC; 2011.

32. Health Protection Surveillance Centre. Influenza surveillance in Ireland - weekly report. Influenza weeks 19 \& 20 (9th to 22nd May 2011). Dublin: Health Protection Surveillance Centre; May 2011. Available from: http://www.hpsc.ie/hpsc/A-Z/ Respiratory/Influenza/Seasonallnfluenza/Surveillance/ InfluenzaSurveillanceReports/PreviousInfluenzaSeasonsSurve illanceReports/20102011Season/

33. Health Protection Surveillance Centre. Influenza surveillance in Ireland - weekly update Influenza week 202010 (17th to 23rd May 2010). Dublin: Health Protection Surveillance Centre, May 2010. Available from: http://www.hpsc.ie/hpsc/A-Z/ Respiratory/Influenza/SeasonalInfluenza/Surveillance/ InfluenzaSurveillanceReports/PreviousInfluenzaSeasonsSurve illanceReports/20092010Season/File,4348,en.pdf

34. Athanasiou M, Baka A, Andreopoulu A, Spala G, Karageorgou $\mathrm{K}$, Kostopoulos L, et al. Influenza surveillance during the postpandemic influenza 2010/2011 season in Greece, 04 October 2010 to 22 May 2011. Euro Surveill. 2011;16(44): pii=2004. Available from: http://www.eurosurveillance.org/ViewArticle. aspx?Articleld $=20004$

35. Scaber J, Saeed S, Ihekweazu C, Efstratiou A, McCarthy N, O’Moore É. Group A streptococcal infections during the seasonal influenza outbreak 2010/11 in South East England. Euro Surveill. 2011;16(5):pii=19780. Available from: http:// www.eurosurveillance.org/ViewArticle.aspx?Articleld $=19780$

36. Davies S. Influenza, meningococcal infection and other bacterial co-infection including pneumococcal and invasive Group A streptococcal Infection (iGAS). London: Department of Health; 10 Jan 2011. Letter. Available from: http://www. dh.gov.uk/en/Publicationsandstatistics/Lettersandcirculars/ Dearcolleagueletters/DH_123646

37. Lowen AC, Mubareka S, Steel J, Palese P. Influenza virus transmission is dependent on relative humidity and temperature. PLoS Pathog. 2007;3(10):e151.

38. Tang JW, Lai FY, Nymadawa P, Deng YM, Ratnamohan M, Petric $M$, et al. Comparison of the incidence of influenza in relation to climate factors during 2000-2007 in five countries. J Med Virol. 2010; 82(11):1958-65.

39. Met Office. Historical climate data. Exeter: Met Office. [Accessed 3 Jul 2011]. Available from: http://www.metoffice. gov.uk/climate/uk/datasets/

40. Medical Products Agency (MPA). Occurrence of narcolepsy with cataplexy among children and adolescents in relation to the $\mathrm{H}_{1} \mathrm{~N}_{1}$ pandemic and Pandemrix vaccinations $\square$ results of a case inventory study by the MPA in Sweden during 2009[2010. Uppsala: MPA; 30 Jun 2011. Available from: http://www.lakemedelsverket.se/upload/nyheter/2011/ Fallinventeringsrapport_pandermrix_110630.pdf

41. Kelly H, Carcione D, Dowse G, Effler P. Quantifying benefits and risks of vaccinating Australian children aged six months to four years with trivalent inactivated seasonal influenza vaccine in 2010. Euro Surveill. 2010;15(37):pii=19661. Available from: http://www.eurosurveillance.org/ViewArticle. aspx?Articleld=19661

42. Higuera Iglesias AL, Kudo K, Manabe T, Corcho Berdugo AE, Corrales Baeza A, Alfaro Ramos L, et al. Reducing occurrence and severity of pneumonia due to pandemic $\mathrm{H}_{1} \mathrm{~N}_{1} 2009$ by early oseltamivir administration: a retrospective study in Mexico. PLoS One. 2011; 6(7):e21838.

43. Kumar A. Early versus late oseltamivir treatment in severely ill patients with 2009 pandemic influenza $A\left(\mathrm{H}_{1} \mathrm{~N}_{1}\right)$ : speed is life. J Antimicrob Chemother. 2011;66(5):959-63.

44. Wang K, Shun-Shin M, Gill P, Perera R, Harnden A. Neuraminidase inhibitors for preventing and treating influenza in children. Cochrane Database Syst Rev. 2012;1:CDo02744.

45. Pebody RG, Harris R, Kafatos G, Chamberland M, Campbell C, Nguyen-Van-Tam JS, et al. Use of antiviral drugs to reduce household transmission of pandemic $\left(\mathrm{H}_{1} \mathrm{~N}_{1}\right) 2009$, United Kingdom. Emerg Infect Dis. 2011;17(6):990-9. Available from: http://wwwnc.cdc.gov/eid/article/17/6/10-1161_article.htm

46. Hatchett RJ, Mecher CE, Lipsitch M. Public health interventions and epidemic intensity during the 1918 influenza pandemic. Proc Natl Acad Sci U S A. 2007;104(18):7582-7.

47. Lee VJ, Yap J, Cook AR, Chen MI, Tay JK, Barr I, et al. Effectiveness of public health measures in mitigating pandemic influenza spread: a prospective sero-epidemiological cohort study. J Infect Dis. 2010;202(9):1319-26. 
48. Fiore AE, Uyeki TM, Broder K, Finelli L, Euler GL, Singleton $J A$, et al. Prevention and control of influenza with

vaccines: recommendations of the Advisory Committee on Immunization Practices (ACIP), 2010. MMWR Recomm Rep. 2010;59(RR-8):1-62.

49. Health Protection Agency (HPA). HPA Weekly national influenza report. Summary of UK surveillance of influenza and other seasonal respiratory illnesses. 8 December 2011 - Week 49. London: HPA; Dec 2010. Available from: http://www.hpa.org. uk/webc/HPAwebFile/HPAweb_C/1317131837604

50. Department of Health. Key vaccine information - seasonal flu. London: Department of Health. [Accessed 3 Jul 2010]. Available from: http://www.dh.gov.uk/en/Publichealth/Immunisation/ Keyvaccineinformation/DH_104070\#_3

51. Office for National Statistics (ONS). Mortality statistics: deaths registered in England and Wales (series DR). (Based on data from 2006-2010). ONS. Available from: http://www.statistics. gov.uk/hub/release-calendar/index.html?newquery $={ }^{\star}$ \&uday $=$ o\& umonth $=0$ \& uyear $=0$ \& title $=$ Mortality + Statistics $\% 3 A+$ Deaths +registered+in+England+and+Wales+\%28Series+DR\%29\&pag etype $=$ calendar-entry $\& \mid d a y=\& l$ month $=\&$ lyear $=$

52. NHS Berkshire. Flu vaccination: information leaflet for clinica staff. NHS Berkshire; 2011. [Accessed 28 Mar 2012]. Available from: http://www.berkshirewest.nhs.uk/_store/documents/ clinician_flu_leaflet_21nov11.pdf

53. Simonsen L, Clarke MJ, Schonberger LB, Arden NH, Cox NJ, Fukuda K. Pandemic versus epidemic influenza mortality: a pattern of changing age distribution. J Infect Dis. 1998;178(1):53-60. 